\section{Seed Longevity of Enterolobium contortisiliquum (Vell.) Morong}

\author{
Maria Fernanda Oliveira Torres ${ }^{1}$ D , Robério Anastácio Ferreira ${ }^{2}$, Laura \\ Catharine Dória Prata ${ }^{3}$ iD, Renata Silva-Mann*3 ${ }^{\text {iD }}$
}

ABSTRACT: Seed storage under controlled temperature and humidity maintains the viability and the vigor of seeds for a long time while preserving their longevity. Ex situ conservation in a seed storage chamber is perfect for simulating the cool dry conditions that are associated with long-term seed storage. This helps to preserve the availability of seeds for the recovery of degraded areas and to ensure a supply of propagating material for various purposes in silvicultural production, or as raw materials for biotechnological use. The present work evaluated the physical and physiological quality of Enterolobium contortisiliquum (Vell.) Morong seeds from an ex situ collection that was kept in a seed storage chamber at $6{ }^{\circ} \mathrm{C} \pm 3^{\circ} \mathrm{C}$ and with $60 \%$ $\pm 5 \%$ of $\mathrm{RH}$ in waterproof packaging. The water content, the physical quality by X-ray tests, germination, electrical conductivity, and the integrity and quality of RNA that was extracted from the embryonic axes were all determined. It was possible to identify full, damaged, malformed, translucent, and empty seeds. The seeds that had been stored for 1, 5, 9, and 10 years presented $78,82,42$, and $38 \%$ of normal seedlings, respectively, while the lots of 6 and 7 years presented 0 and $6 \%$. The seed storage conditions were the same for all of the lots. A water content higher than $6 \%$ influenced the quality of the seeds. The E. contortisiliquum seeds demonstrated high longevity. They could be stored for up to 10 years under controlled conditions.

Index terms: X-ray, viability, ex situ conservation, monkfish.

\section{Longevidade de sementes de Enterolobium contortisiliquum (Vell.) Morong}

RESUMO: O armazenamento de sementes sob condições controladas de temperatura e umidade mantém a viabilidade e o vigor das sementes por um longo tempo, preservando sua longevidade. Esse tipo de conservação ajuda a preservar a disponibilidade de sementes para a recuperação de áreas degradadas, ou para garantir o fornecimento de material propagador para diversas finalidades na produção silvicultural, ou como matérias-primas para uso biotecnológico. $O$ presente trabalho avaliou a qualidade física e fisiológica de sementes de Enterolobium contortisiliquum (Vell.) de uma coleção ex situ armazenada em câmara fria a $6{ }^{\circ} \mathrm{C}$ $\pm 3^{\circ} \mathrm{C}$ e $60 \% \pm 5 \%$ de UR em embalagem impermeável. $O$ teor de água, a qualidade física por testes de raio- $X$, a germinação, a condutividade elétrica, a integridade e a qualidade do RNA extraído dos eixos embrionários foram todos determinados. Foi possível identificar sementes completas, danificadas, malformadas, translúcidas e vazias. As sementes armazenadas por 1, 5, 9 e 10 anos apresentaram 78, 82, 42 e 38\% das plântulas normais, respectivamente, enquanto os lotes de 6 e 7 anos apresentaram 0 e $6 \%$. As condições de armazenamento das sementes foram as mesmas para todos os lotes. 0 teor de água superior a $6 \%$ influenciou a qualidade das sementes. As sementes de $E$. contortisiliquum demonstraram alta longevidade e podem ser armazenadas por até 10 anos em condições controladas.

Termos para indexação: raio-x, viabilidade, conservação ex situ, tamboril.
Journal of Seed Science, v.42, e202042032, 2020

http://dx.doi.org/10.1590/ 2317-1545v42239618
*Corresponding Author Email: renatamann@academico.ufs.br

Received: 6/15/2020.

Accepted: 7/29/2020.

${ }^{1}$ Programa de Pós-Graduação em Agricultura e Biodiversidade, Universidade Federal de Sergipe, São Cristóvão, SE, Brasil.

${ }^{2}$ Departamento de Ciências Florestais, Universidade Federal de Sergipe, São Cristóvão, SE, Brasil.

${ }^{3}$ Departamento de Engenharia Agronômica, Universidade Federal de Sergipe, São Cristóvão, SE, Brasil. 


\section{INTRODUCTION}

Seed storage is an ex situ conservation strategy that is influenced by several factors, from physiological quality to maintaining the viability of the seeds (Guedes et al., 2012). Storage under controlled low temperatures and relative humidity act in seed conservation, such as those that are performed in cold chambers (Hong and Ellis, 2002). This is because they cover a large volume of germplasm accessions or lots, in addition to being more efficient and economical in energy terms when compared to the use of several freezers for the same purpose (Lingington and Manger, 2014).

Seed storage, when well established in this type of environment, is associated with the use of impermeable packaging. This constitutes a condition for preserving the longevity of the seeds from forest species with an orthodox character (Silva et al., 2014; Oliveira-Bento et al., 2015). Therefore, quality monitoring is necessary to minimize the losses in silvicultural processes.

E. contortisiliquum (Vell.) Morong is a forest species that is native to Brazil. It is from the tree family Fabaceae, subfamily Mimosoideae, and it is included in the successional group climax series that demands light (Oliveira-Filho et al., 1995). As orthodox seeds (Barretto and Ferreira, 2011), they tolerate storage at low temperatures, but there is a lack of information in the literature on these storage conditions, together with the relationship between their physiological qualities and their internal morphology.

This species, commonly known as monkey ear or monkfish, has biotechnological properties as a protease inhibitor (Oliva et al., 2007). In times of viruses and pandemics, the infectivity of a population of enveloped viruses is comprised of a protein that is anchored by the membrane glycosylphosphatidylinositol and this can be reduced by using toxins, such as enterolobin, which is obtained from monkfish. These toxins can be used to produce attenuated viral vaccines, in order to purify blood products, cells, or the tissues from viruses, and to detect viruses in samples (Hildreth et al., 2002). Thus, the knowledge of the physiology of monkfish seeds that are stored for up to ten years can be useful for defining conservation strategies that are aimed at obtaining seedlings and raw materials for biotechnological research and industries. The aim of the present work was to evaluate the physical and physiological quality of Enterolobium contortisiliquum (Vell.) Morong seeds when stored under controlled low temperatures and relative humidity in an ex situ collection.

\section{MATERIAL AND METHODS}

The seed samples were composed of fruits that were harvested from different matrices located in the municipalities of Aracaju, Capela, Lagarto, Moita Bonita, and Santana do São Francisco. These municipalities have the same climate conditions as tropical monsoons (As) (Kottek et al., 2006). The seeds were harvested in the years 2007, 2008, 2010, 2011,2012 , and 2016 and then stored at $6 \pm 3^{\circ} \mathrm{C}$.

After harvesting, the fruits were manually processed with the aid of a rubber hammer, in order to remove the seeds. The seeds were packed in transparent waterproof plastic packages and kept in a cold chamber at $6{ }^{\circ} \mathrm{C} \pm 3{ }^{\circ} \mathrm{C}$, with $60 \%$ $\pm 5 \%$ RU. These conditions were maintained until the testing in 2017. At the beginning of the tests, six treatments were defined and they were named according to the storage time of each lot as 1-year (2016), 5-years (2012), 6-years (2011), 7-years (2010), 9-years (2008), and 10-years (2007). The lots were composed of seeds from different Brazilian provenances and they were located under weather conditions that are known as tropical monsoons (As) (Kottek et al., 2006).

The seed harvesting were carried out by a working group that was responsible for projects to recover the degraded areas in the State of Sergipe, Brazil. The seeds were harvested and immediately stored, without concern for determining the initial quality. They were then sent to the Forest Nursery for the production of the seedlings. These conditions were maintained for all of the lots until 2017.

The water contents were determined first in an oven at $105^{\circ} \mathrm{C} \pm 3^{\circ} \mathrm{C}$ for $24 \mathrm{~h}$ using two replications of $5 \mathrm{~g}$ of seeds (Brasil, 2009) and then by infrared equipment (TOP-RAY) using four replications of $5 \mathrm{~g}$ of fragmented seeds. 
In the X-ray tests, 200 seeds from each lot were divided into eight replications of 25 seeds and radiographed at 22 kV for 5.8 seconds (Faxitron ${ }^{\circledR}$ X-Ray Corp Model HP MX-20) (Brasil, 2009). Each seed was individually identified for further evaluation by the germination tests. The images were analyzed by the ImageJ program, version 1.49s (Abràmoff et al., 2004).

The seeds were scarified by immersion in sulfuric acid $\left(\mathrm{H}_{2} \mathrm{SO}_{4}\right)(98 \%)$ for $40 \mathrm{~min}$, followed by a triple washing with distilled water. They were then washed, sieved, and inserted into a layer of sterilized sand at $120^{\circ} \mathrm{C}$ for 24 hours. Afterward, they were then arranged to germinate on the substrate in trays at $25^{\circ} \mathrm{C}$, with a $12: 12$ hour photoperiod. The evaluations were carried out every $48 \mathrm{~h}$ for 30 days. From the evaluations, the germination speed index (GSI) (Maguire, 1962) and the Average Time of Seed Germination (ATSG) (Labouriau, 1983) were calculated.

Electrical conductivity was carried out in the lots of 5, 6, 7, and 9 years. These years were chosen according to the availability of the seeds. The determinations were carried out at $25^{\circ} \mathrm{C}$ and $40{ }^{\circ} \mathrm{C}$ by using four replications of 25 seeds that were soaked for $24 \mathrm{~h}$ in $75 \mathrm{~mL}$ of ultrapure water while under dark conditions (Santos and Paula, 2005). The readings were obtained by using an electrical conductivity meter (Marconi ${ }^{\circledR}$ model MA-521).

The seeds were soaked for $24 \mathrm{~h}$ and the embryonic axes were removed for the extraction of the RNA (NucleoSpin ${ }^{\circledR}$ RNA II, Macherey-Nagel). Each lot was represented for RNA evaluation by using the method of bulk sampling with 10 embryos. The RNA was quantified and qualified by the nano spectrophotometry ratio at $260 / 280 \mathrm{~nm}$. In order to assess the integrity, $1 \mu \mathrm{g}$ of RNA was submitted to electrophoresis in a 1\% polyacrylamide gel, whilst using silver staining.

The experiments were completely randomized and the variables were tested for an adjustment to a normal distribution by the Shapiro-Wilk test. The germination data had its means transformed by arco.seno $(x / 100)$. The data was subjected to an analysis of variance by the $\mathrm{F}$ test and the averages were compared by the Tukey test for the data of germination and electrical conductivity. The pixel density data had its means grouped by the Scott-Knott test at the level of 5\% probability (Ferreira, 2011). The variables that were used in the categorization of internal morphology by the X-rays and germination were subjected to the Factor evaluation and Principal Components Analysis. The degree of association between the variables was determined by the covariance matrix, where the loads that presented an absolute value higher than 0.7 were considered relevant. For the dispersion graph, the eigenvalue correlation matrix was used and eigenvalues higher than 1.0 were extracted (Kaiser, 1960). In this work, the orthogonal rotation procedure

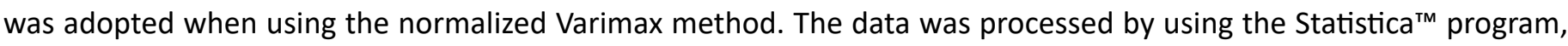
version 7.0 , and all of the variables were standardized.

\section{RESULTS AND DISCUSSION}

The seeds that were 1-year-old and 5-years-old presented high viability and vigor, with low water content, low electrical conductivity, and high pixel density (GPDL) (Table 1).

Furthermore, for the General Pixel Density of the Lot (GPDL) variable, there was a considerable reduction after 5 years of storage, which may be associated with tissue degradation. Regarding the internal morphology, the one-year lot had $90 \%$ of full seeds, $67.5 \%$ of normal seedlings, $12.5 \%$ of abnormal seedlings, and $10 \%$ of deteriorated seeds. For the 5 -year lot, $62.5 \%$ of the seeds were classified as full and they resulted in normal seedlings (Table 1 ).

The oldest lots (2007 and 2008) showed germination of $44.5 \%$ and $38 \%$ and they were classified as full by the X-ray tests (Figure 2). The radicle emissions started at $48 \mathrm{~h}$ after sowing for the 1-year and 5-year lots (Figure 3). The pixel densities also allowed for the identification of damaged or malformed seeds and they varied according to the structure, the composition, and the thickness of the reserve tissue (ISTA, 2004). The germination started on the eighth day and both of these lots showed the highest vigor (Figure 4). Most of the seeds were classified as full (66 to $90 \%$ ), followed by damaged ( 2.85 to $14.5 \%$ ), malformed ( 3 to $13.5 \%$ ), and empty ( 0 to $1 \%$ ) (Figure 1 ).

For the 6, 7, and 9 years, there were empty seeds, with the highest number of abnormal seedlings. The seed viability proved that the storage conditions for the species were an efficient means of ex situ conservation for up to ten years (Figure 2). 
M. F. O. Torres et al.

Table 1. Categories of the Enterolobium contortisiliquum (Vell.) Morong seeds that were obtained by the X-ray tests from the lots that were stored in a cold storage chamber when compared to the germination tests. NS Normal Seedlings; AS - Abnormal Seedlings; D - Deteriorated Seeds.

\begin{tabular}{|c|c|c|c|c|c|c|c|}
\hline \multirow{2}{*}{ Time (year) } & \multirow{2}{*}{ Water content (\%) } & \multirow{2}{*}{ GPDL* } & \multirow{2}{*}{ Category } & \multirow{2}{*}{ Total (\%) } & \multicolumn{3}{|c|}{ Germination } \\
\hline & & & & & NS\% & AS\% & $\mathrm{D} \%$ \\
\hline & & & With Damage & 4.00 & 3.00 & 0.50 & 0.50 \\
\hline & & & Malformed & 3.00 & 2.50 & 0.50 & 0.00 \\
\hline \multirow[t]{6}{*}{1} & 4.61 & $177.25 \mathrm{a}$ & Full & 90.00 & 69.00 & 11.00 & 10.00 \\
\hline & & & Translucent & 3.00 & 2.00 & 0.00 & 0.50 \\
\hline & & & Empty & 0.00 & 0.00 & 0.00 & 0.00 \\
\hline & & & Total & 100.00 & 77.00 & 12.00 & 11.00 \\
\hline & & & With Damage & 7.50 & 6.50 & 1.00 & 0.00 \\
\hline & & & Malformed & 7.50 & 6.00 & 0.50 & 1.00 \\
\hline \multirow[t]{6}{*}{5} & 7.31 & $181.10 \mathrm{a}$ & Full & 79.50 & 64.50 & 5.00 & 10.00 \\
\hline & & & Translucent & 5.50 & 5.00 & 0.50 & 0.00 \\
\hline & & & Empty & 0.00 & 0.00 & 0.00 & 0.00 \\
\hline & & & Total & 100.00 & 82.00 & 7.00 & 11.00 \\
\hline & & & With Damage & 14.50 & 0.00 & 0.00 & 14.50 \\
\hline & & & Malformed & 9.00 & 0.00 & 0.00 & 9.00 \\
\hline \multirow[t]{6}{*}{6} & 15.41 & $152.75 b$ & Full & 74.50 & 0.00 & 0.00 & 74.50 \\
\hline & & & Translucent & 2.00 & 0.00 & 0.00 & 2.00 \\
\hline & & & Empty & 0.00 & 0.00 & 0.00 & 0.00 \\
\hline & & & Total & 100.00 & 0.00 & 0.00 & 100.00 \\
\hline & & & With Damage & 13.50 & 0.00 & 1.00 & 12.50 \\
\hline & & & Malformed & 8.50 & 0.00 & 0.00 & 8.50 \\
\hline \multirow[t]{6}{*}{7} & 12.43 & $150.12 b$ & Full & 66.00 & 5.00 & 16.00 & 45.00 \\
\hline & & & Translucent & 11.00 & 0.50 & 0.00 & 10.50 \\
\hline & & & Empty & 1.00 & 0.00 & 0.00 & 1.00 \\
\hline & & & Total & 100 & 5.5 & 17.5 & 77.5 \\
\hline & & & With Damage & 2.86 & 0.57 & 0.00 & 2.29 \\
\hline & & & Malformed & 13.71 & 0.50 & 0.00 & 18.86 \\
\hline \multirow[t]{6}{*}{9} & 12.13 & $122.37 b$ & Full & 73.15 & 50.86 & 16.57 & 5.14 \\
\hline & & & Translucent & 9.71 & 1.14 & 2.29 & 6.28 \\
\hline & & & Empty & 0.57 & 0.00 & 0.00 & 0.57 \\
\hline & & & Total & 100 & 53.0 & 18.85 & 27.48 \\
\hline & & & With Damage & 4.00 & 0.00 & 1.00 & 3.00 \\
\hline & & & Malformed & 4.00 & 1.00 & 1.00 & 2.00 \\
\hline \multirow[t]{3}{*}{10} & 12.97 & $130.75 \mathrm{~b}$ & Full & 89.00 & 35.50 & 41.50 & 12.00 \\
\hline & & & Translucent & 3.00 & 1.50 & 1.50 & 0.00 \\
\hline & & & Empty & 0.00 & 0.00 & 0.00 & 0.00 \\
\hline CV\% & 24.29 & 25.84 & Total & 100.00 & 38.00 & 44.00 & 17.00 \\
\hline
\end{tabular}

* Mean values followed by the same lowercase letter in the column did not differ statistically by the Scott-Knott test at $5 \%$ probability. 

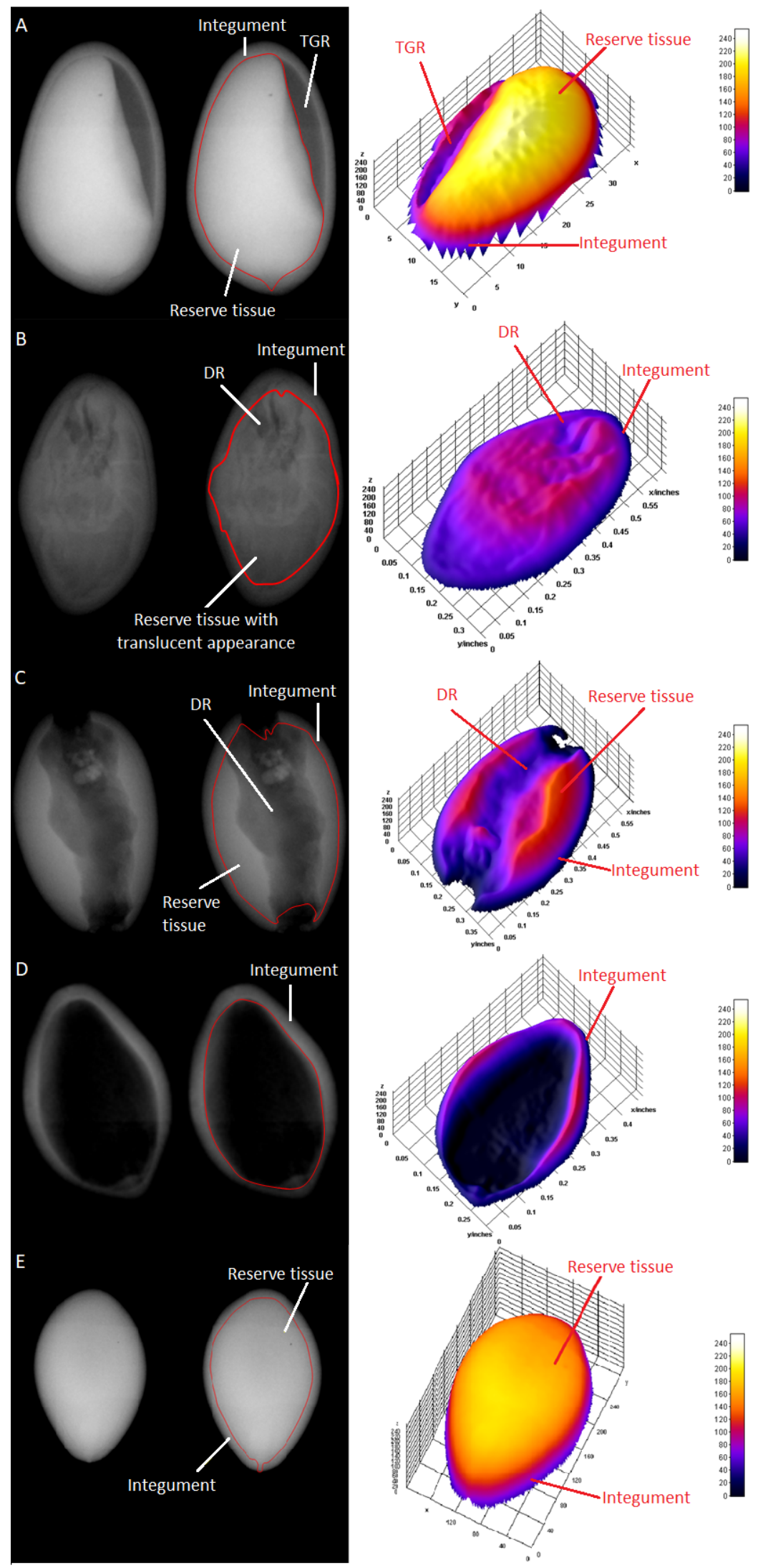

Figure 1. Images from the X-ray tests of the seeds of Enterolobium contortisiliquum (Vell.) Morong when evaluated by ImageJ software. The seeds were classified as malformed (A), translucent (B), damaged (C), empty (D), and flooded (E). TGR - Tegumentar region; DR - Damaged region. 
The highest number of abnormal seedlings occurred in the 10-year-lot (44\%) (Figure 2C). The lowest radicle emissions (21 and 0\%) and seedlings (15 and 0\%) were for the 7 and 6-year lots, respectively. The highest values of the deteriorated seeds reached 79 and $100 \%$ (Figure 2D) for both of the latter cited lots. The negative results of these last two lots were probably related to the high water content in the seeds (above 15\%). The seeds that are stored with a high water content can maintain their active metabolism, while at the same time, accentuating the effects of deterioration and the actions of the microorganisms, thus losing their ability to germinate (Resende et al., 2011) and affecting their longevity. For seeds of this species, storage with water content close to $8 \%$ is recommended (Wielewicki et al., 2006).
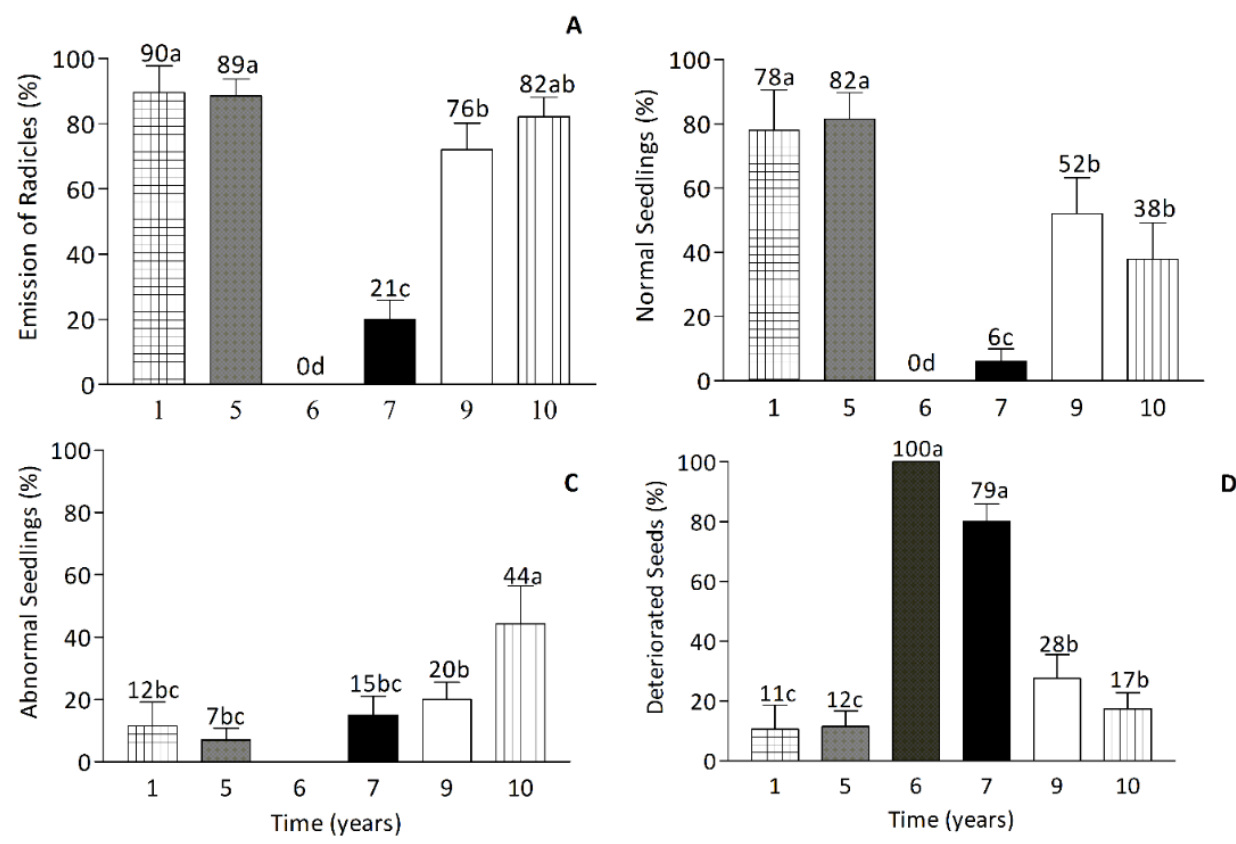

Figure 2. Viability of the seeds of Enterolobium contortisiliquum (Vell.) Morong that were kept in a cold storage chamber. A - Emission of radicles on the eighth day; B - Normal Seedlings; C - Abnormal Seedlings; D - Deteriorated Seeds. Mean values followed by the same letter between the lots did not differ statistically at a $5 \%$ probability by the Tukey test.

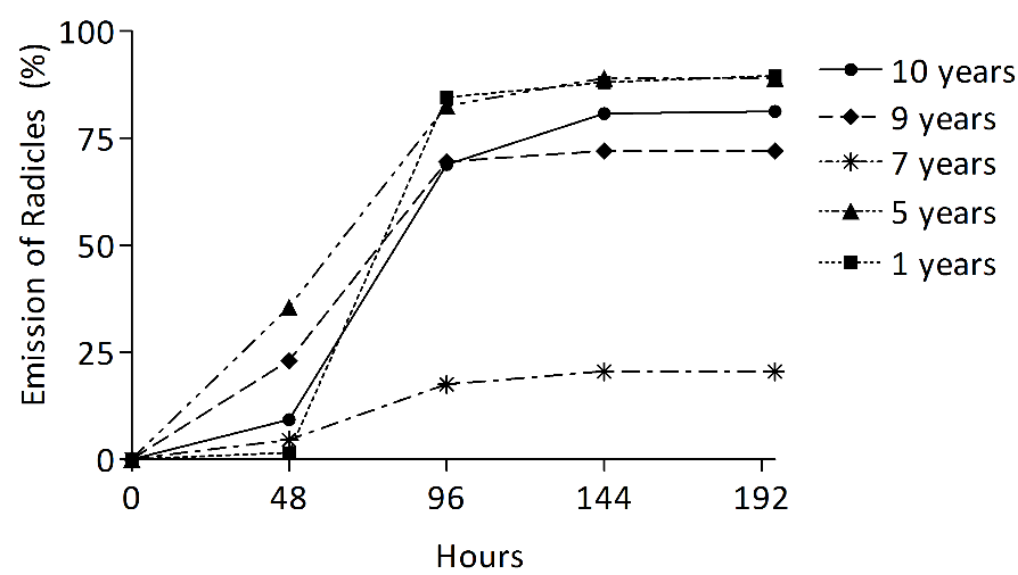

Figure 3. The percentages of the radicles that were emitted from the Enterolobium contortisiliquum (Vell.) Morong storage seeds. 
The monkfish germination was relatively slow (Figure 4). The average time of seed germination (ATSG) is shown in Figure 5. The germination speed index (GSI) is presented in Figure 6). The 1-year-old and 5-years-old presented high germination speed index (GSI).

Slow germination can be associated with dormancy, which can be positive at an ecological level, but it is negative at a silvicultural level, as it delays the seedling production process (Costa et al., 2011; Freitas et al., 2016).

Regarding electrical conductivity (EC), differences were observed in the four lots (Figure 7).

The use of different temperatures in the electrical conductivity tests was relevant, especially when there was a low variation among the lots. The electrical conductivity test when measured at $40{ }^{\circ} \mathrm{C}$ can function as a vigor test and it can differentiate the seed quality. High temperatures in the EC test led to an increase in the speed of leaching of the seeds (Ribeiro et al., 2009). This strategy can be used in seeds with rigid integuments, even with the breaking of dormancy.

The data from the X-ray tests, the germination tests, and the vigor tests were submitted to Factor analyses (Table 2). Only components 1, 2, and 3 were dependable enough to explain the variations that occurred. From the principal component analyses (PCA), it was possible to explain $92.98 \%$ of the variances that were contained in the studied variables (Table 2).

Principal component 1 (CP1) explained about $40.63 \%$ of the aggregated variable seeds, with damage, viability, vigor, and deteriorated seeds revealed. Principal component 2 (CP2) explained that about 31.26\% of the total

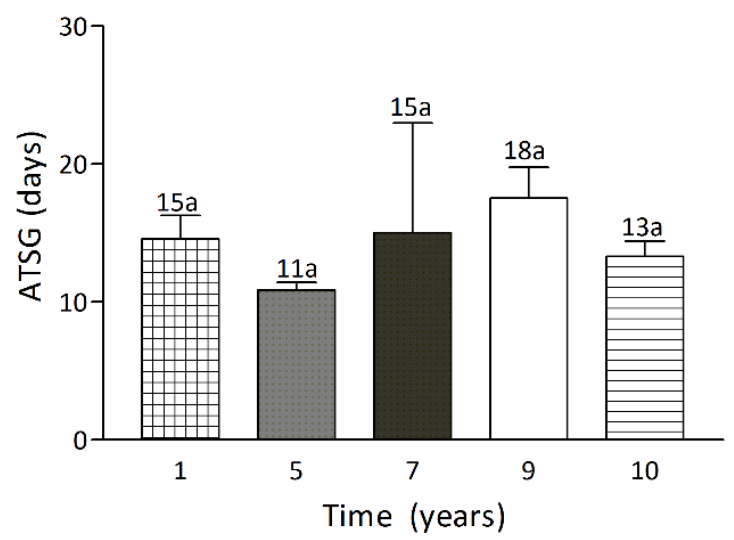

Figure 4. Average Time of Seed Germination (ATSG) of the stored seeds of Enterolobium contortisiliquum (Vell.) Morong. Mean values followed by the same letter between the lots did not differ statistically at a $5 \%$ probability by the Tukey test.

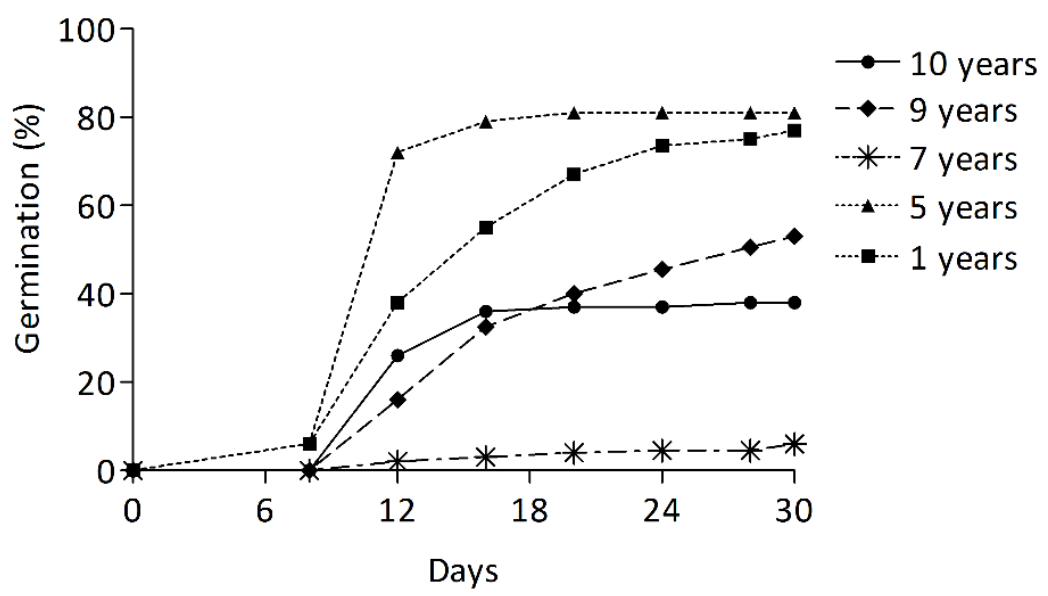

Figure 5. Germination percentages (\%) of the stored seeds of Enterolobium contortisiliquum (Vell.) Morong. 


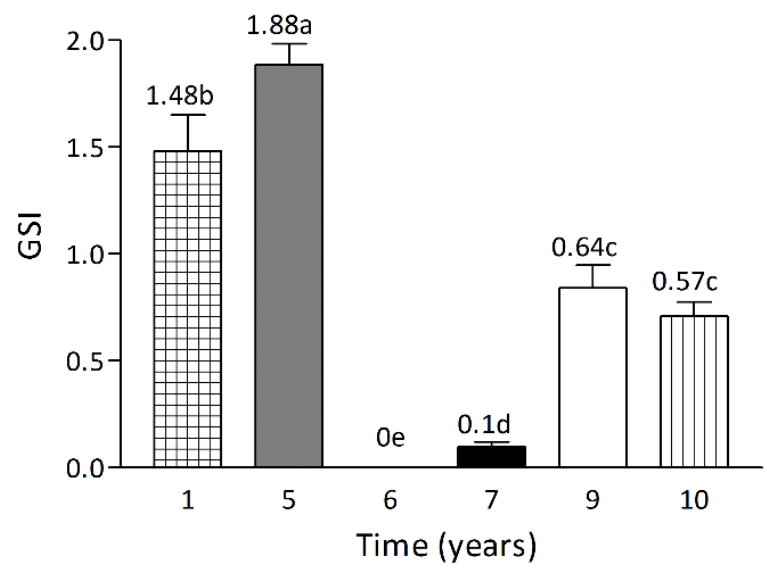

Figure 6. Germination Speed Index (GSI) of the seed lots of Enterolobium contortisiliquum (Vell.) Morong that were kept in a cold storage chamber. Mean values followed by the same letter between the lots did not differ statistically at a $5 \%$ probability by the Tukey test.

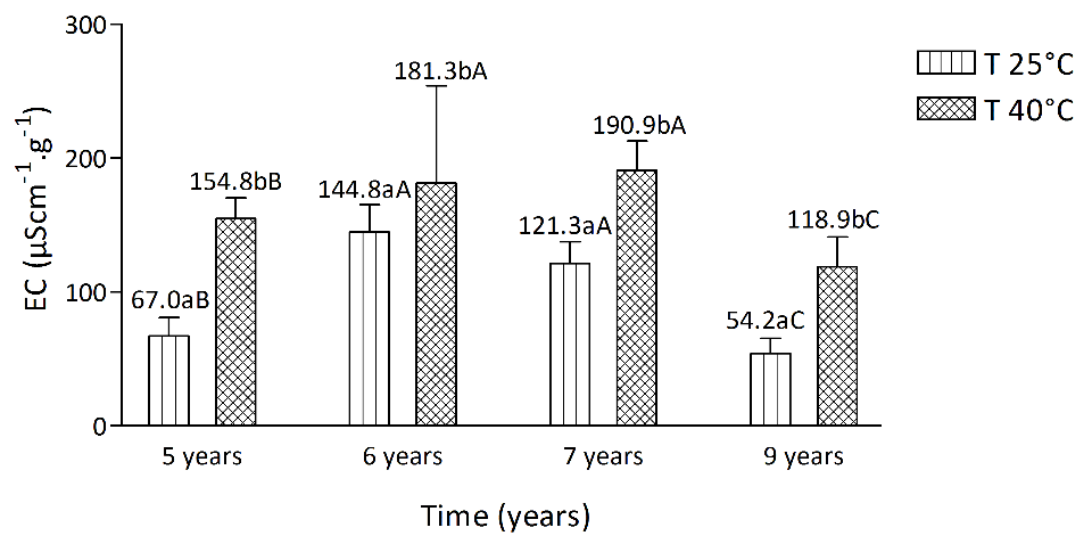

Figure 7. Electrical conductivity (EC) of the stored seed lots of Enterolobium contortisiliquum (Vell.) Morong under different temperatures $\left(25^{\circ} \mathrm{C}\right.$ and $\left.40{ }^{\circ} \mathrm{C}\right)$. Mean values followed by the same letter between the lots did not differ statistically at a $5 \%$ probability by the Tukey test.

data variance was represented by the variables of full, poorly formed, translucent, and empty seeds. Thus, it can be deduced that this component was linked to the internal morphological characteristics of the seeds that were determined by the $\mathrm{X}$-ray tests.

Although the variable seeds with damage were detected during the X-ray tests, it is worth mentioning that this was not always due to a condition during their formation process. This could have been caused by mechanical and/or insect damage, which would explain the position of the load on CP1. Regarding main component 3 (CP3), it explained that $21.09 \%$ of the variation was represented by the variable pixel density and the water content. The water contents influenced the quality of the images that were obtained by the X-ray tests (Nogueira-Filho et al., 2017; Jeromini et al., 2019). These types of characteristics can vary with the type of seed (recalcitrant or orthodox) and reserve tissue. Therefore, CP3 presented a relationship with the physicochemical characteristics of the seeds. In the literature, it is mentioned that the water content can make it difficult to standardize the results, as it influences the images (Silva et al., 2014).

There were simple correlation coefficients for germination, vigor, water content, and data from the X-ray tests (Table 3).

Only the correlations with a significance equal to or higher than 0.5 were considered. There was a high positive and significant correlation of the damaged, translucent, and empty seeds when related to vigor and viability. 
Table 2. Factor loads of the variables that were analyzed for the main components. CF - Factorial loads.

\begin{tabular}{lcccc}
\hline \multicolumn{1}{c}{ Variable } & CF 1 & CF 2 & CF3 & Commonalities \\
\hline Damaged seeds & -0.946731 & -0.151523 & 0.256522 & 0.985062 \\
Malformed seeds & -0.129165 & 0.735010 & 0.359755 & 0.686347 \\
Full seed & -0.555155 & 0.812620 & 0.038336 & 0.970018 \\
Translucent seed & 0.061374 & 0.976348 & 0.068189 & 0.961672 \\
Empty seed & -0.215213 & 0.893092 & 0.125038 & 0.859564 \\
Viability & 0.892711 & -0.116919 & -0.397600 & 0.968688 \\
Vigor & 0.804339 & -0.160130 & -0.526274 & 0.949568 \\
Decayed seed & 0.965279 & -0.174975 & -0.119778 & 0.976726 \\
Pixel Density & -0.007635 & 0.261585 & 0.962605 & 0.995092 \\
Water content & -0.645389 & 0.118204 & 0.718400 & 0.946599 \\
\hline Eigenvalue & 5.63 & 2.21 & 1.44 & - \\
Total change (\%) & 56.36 & 22.14 & 14.47 & - \\
Accumulated variation (\%) & 56.36 & 78.51 & 92.99 & - \\
Explained variance (\%) & 40.63 & 31.26 & 21.09 & \\
\hline
\end{tabular}

Table 3. Correlation matrix between the factor loads of the morphophysiological quality variables. Wd - With damage; Mf-malformed; T - translucent, F - feasibility; Det - deteriorated; Pixel D - Pixel density; WC - Water content.

\begin{tabular}{ccccccccccc}
\hline Variable & Wd & Mf & Full & T & Empty & F & Vigor & Det & Pixel D & WC \\
\hline Wd & 1.00 & $0.16^{\text {ns }}$ & $-0.65^{\text {ns }}$ & $0.07^{\text {ns }}$ & $0.28^{\text {ns }}$ & $-0.75^{\text {ns }}$ & $-0.63^{\text {ns }}$ & $0.90^{*}$ & $0.20^{\text {ns }}$ & $0.47^{\text {ns }}$ \\
Mf & - & 1.00 & $-0.77^{\text {ns }}$ & $0.63^{\text {ns }}$ & $0.53^{\text {ns }}$ & $-0.25^{\text {ns }}$ & $-0.32^{\text {ns }}$ & $0.35^{\text {ns }}$ & $-0.50^{\text {ns }}$ & $0.49^{\text {ns }}$ \\
Full & - & - & 1.00 & $-0.74^{\text {ns }}$ & $-0.79^{\text {ns }}$ & $0.58^{\text {ns }}$ & $0.56^{\text {ns }}$ & $-0.69^{\text {ns }}$ & $0.24^{\text {ns }}$ & $-0.51^{\text {ns }}$ \\
T & - & - & - & 1.00 & $0.93^{*}$ & $-0.12^{\text {ns }}$ & $-0.17^{\text {ns }}$ & $0.10^{\text {ns }}$ & $-0.33^{\text {ns }}$ & $0.11^{\text {ns }}$ \\
Empty & - & - & - & - & 1.00 & $-0.41^{\text {ns }}$ & $-0.46^{\text {ns }}$ & $0.36^{\text {ns }}$ & $-0.38^{\text {ns }}$ & $0.28^{\text {ns }}$ \\
F & - & - & - & - & - & 1.00 & $0.98^{*}$ & $-0.92^{*}$ & $0.43^{\text {nd }}$ & $-0.85^{*}$ \\
Vigor & - & - & - & - & - & - & 1.00 & $-0.87^{*}$ & $0.57^{\text {ns }}$ & $-0.87^{*}$ \\
Det & - & - & - & - & - & - & - & 1.00 & $-0.16^{\text {ns }}$ & $0.71^{\text {ns }}$ \\
Pixel D & - & - & - & - & - & - & - & - & 1.00 & $-0.72^{\text {ns }}$ \\
WC & - & - & - & - & - & - & - & - & - & 1.00 \\
\hline
\end{tabular}

ns: non-significant; ${ }^{*}$ significant at $5 \%$

Significant and negative correlations were observed between the water content and the deteriorated seeds in relation to viability and vigor.

There were strong negative correlations between the water content and vigor and viability. The lot that was stored for 6 -years had a high water content (15.41\%) and with $74.5 \%$ of its seeds classified as full. However, $100 \%$ of these propagules deteriorated. The 7 -year-old lot had a water content equal to $12.43 \%$ and only $5 \%$ of the seeds germinated. Factors 1 and 2 were important and expressive components since together, they covered about $78.5 \%$ of the total variations (Figure 8).

The vigor and viability variables showed large positive rotational factor loads in Factor 1 . Factor 1 described the relevance of the more vigorous lots, with those with a higher number of full seeds, which would result in higher germinations. 
Thus, high pixel density and high physiological quality could be present in the seeds if the water content was within the recommended standards. Therefore, the deteriorated seeds, the water content, the empty, the malformed, and the translucent seeds had positive and far from zero factor loads for CP 2, reflecting their correlation with the low vigor lots.

In assessing RNA, it can be pointed out that 5 of the 6 lots showed decontaminated samples. It was noteworthy that the quality of RNA cannot be considered as an indication of purity, due to the presence of other molecules, such as DNA and proteins (Manning, 1991). In this work, the lot that lowered the desired standard was the 7-year lot. In general, the samples showed enough quantity, quality, and integrity in according to Asif et al. (2006) (Figure 9).

An electrophoretic profile that was distinct from the others was obtained from the 6-year lot. It was observed that with a low water content, it was possible to lower the metabolic activities, the respiration, and the action of the microorganisms (Peskeet al., 2012; Resende et al., 2011). Some species of seeds can be submitted to a drying treatment and preserve their germination percentages, while other species can suffer physiological damage when they are dried (Faria et al., 2014).

It was expected that the longer storage time results would lower the physiological quality of the seed lots. However, there was a factor of relevance, the water content. For seeds of this species, a water content close to $8 \%$ is recommended for their storage (Wielewicki et al., 2006). Water contents above 5-8\% could cause RNA damage, as was observed in the lots of 9 and 10 years. An increase in storage time, with a consequent reduction in seed vigor, can be expected (Garcia et al., 2014; Rocha et al., 2017). The seeds that showed the highest RNA deterioration were the same as the ones with the highest EC values. A significant correlation between the germination test and EC has been reported, which is an alternative for a quick assessment of the physiological quality of the seeds (Guollo et al., 2017). Those seeds that are in an advanced deterioration process may have failures or slow cell membrane repair speed during water retention for germination (Beedi et al., 2018).

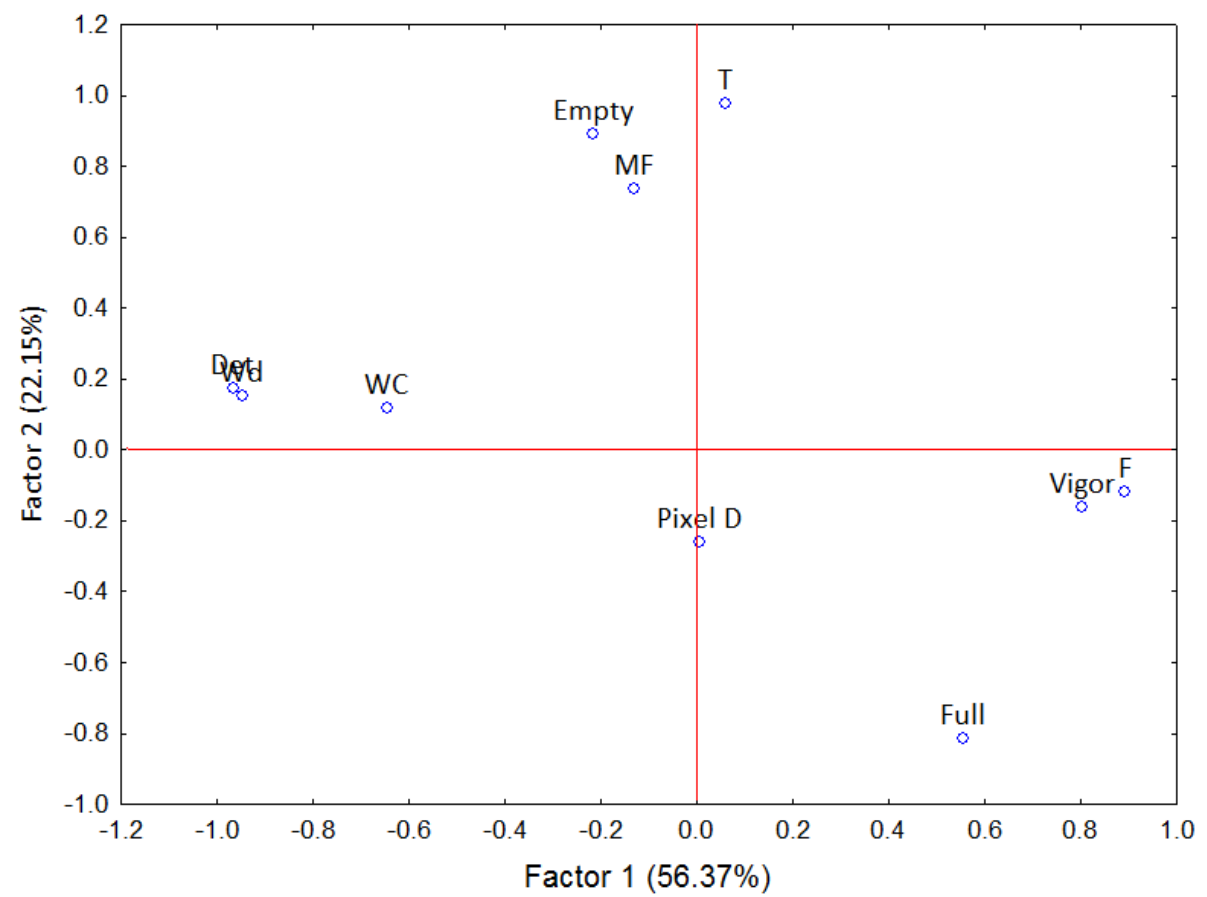

Figure 8. Percentages in the Figure Graph represent the relationship between Factor 1 and Factor 2, together with the variables that were analyzed in the X-ray tests and in the germination tests of the $E$. contortisiliquum seeds that were stored for up to ten years. WC - Water content; Pixel D - Pixel density; Wd - With damage; Det deteriorated; $\mathrm{T}$ - translucent, Mf - malformed; $\mathrm{F}$ - feasibility. 


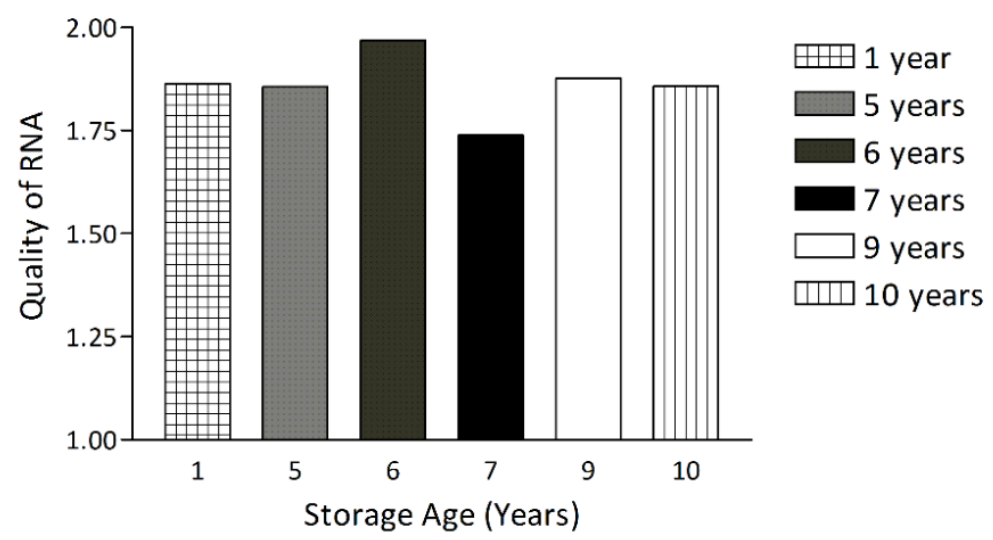

Figure 9. RNA quality of the E. contortisiliquum (Vell.) Morong seeds that depended on the storage time.

The 6-year-old lot presented an excessive amount of deteriorated seeds (100\%), the highest EC, and a lack of RNA integrity. In the seeds of Pisum sativum L., it was noticed that the DNA fragmentation decreased after imbibition, while the integrity of the rRNA was lost and was not restored (Kranner et al., 2011). With storage, the RNA molecules are reported to be reduced in the seeds by oxidative reactions that culminate in a loss of germination (Fleming et al., 2017). During imbibition, the seeds have the potential to restore their membranes (Silva and Villela, 2011) and this restoration is related to the integrity of the RNAs.

After all of the observations, the authors can summarize that the loss of seed quality can vary according to the conditions of the environment, the packaging, and the storage time.

The initial quality of the orthodox seeds is essential for success in an ex situ conservation, as it is able to align production, processing, and seed removal, with subsequent conservation (Vergara et al., 2020). The aging of seeds is inexorable, resulting in a drop in vigor and subsequent death (Garcia et al., 2014; Rocha et al., 2017). The main goal is always to maintain the viability of the seeds. The conservation of orthodox seeds in a germplasm bank is not to be recommended for those that present less than $60 \%$ of germination. In these cases, the seed lots must be renewed. However, native species are increasingly difficult to manage since there is an intermittent and scarce production, mainly due to climate changes, incompatibility alleles, and pollinators. In this regard, seed discarding, even with a viability of less than $60 \%$, may imply the loss of genetic resources that can be used to produce seedlings for the recovery and the restorations of the degraded areas.

\section{CONCLUSIONS}

It is possible to store full, whole, and low humidity seeds of $E$. contortisiliquum for periods of up to 10 years. The seeds can be stored for 5 years, without reducing their viability and their vigor. When stored for longer than 5 years, the physiological quality of the seeds undergo changes, resulting in reduced viability and vigor. The longevity of the seeds of E. contortisiliquum under controlled storage conditions allows for their ex situ conservation for up to ten years.

\section{ACKNOWLEDGMENTS}

The authors would like to thank Dr. Juliana Lopes Souza and MSc Valdinete Vieira Nunes for their support in the laboratory analyses. The authors would like to thank the Coordination for the Improvement of Higher Education Personnel (CAPES) for the scholarship of the first author. 


\section{REFERENCES}

ABRÀMOFF, M.D.; MAGALHÃES, P.J.; RAM, S.J. Image processing with ImageJ. Biophotonics International, v.11, n.7, p.36-42, 2004. https://dspace.library.uu.nl/handle/1874/204900

ASIF, M.; TRIVEDI, P.; SOLOMOS, T.; TUCKER, M. Isolation of high-quality RNA from apple (Malus domestica) fruit. Journal of Agricultural and Food Chemistry, v.54, n.15, p.5227-5229, 2006. https://doi.org/10.1021/jf053137n

BARRETTO, S.S.B.; FERREIRA, R.A. Aspectos morfológicos de frutos, sementes, plântulas e mudas de Leguminosae Mimosoideae: Anadenanthera colubrina (Vellozo Brenan e Enterolobium contortisiliquum (Vellozo) Morong. Revista Brasileira de Sementes, v.33, n.2, p.223 - 232, 2011. http://www.scielo.br/scielo.php?script=sci_arttext\&pid=S0101-31222011000200004\&lng=en\&nrm=iso

BEEDI, S.; MACHA, S.I.; GOWDA, B.; SAVITHA, A.S.; KURNALLIKAR, V. Effect of seed priming on germination percentage, shoot length, root length, seedling vigor index, moisture content, and electrical conductivity in the storage of Kabuli Chickpea cv., MNK-1 (Cicer arietinum L.). Journal of Pharmacognosy and Phytochemistry, v.7, n.1, p.2005-2010, 2018. http://www.phytojournal.com/ archives/2018/vol7issue1/PartAB/7-1-386-370.pdf

BRASIL. Ministério da Agricultura, Pecuária e Abastecimento. Regras Para Análise de Sementes. Ministério da Agricultura, Pecuária e Abastecimento. Secretaria de Defesa Agropecuária. Brasília, DF: Mapa/ACS. 2009. 395p. https://www.abrates.org.br/files/ regras_analise_de_sementes.pdf.

COSTA, T.G.; DIAS, A.H.D.S.; ELIAS, T.D.F.; BREIER, T.B.; ABREU, H.D.S. Lignina e a dormência em sementes de três espécies de leguminosas florestais da Mata Atlântica. Floresta e Ambiente, v.18, n.2, p.204-209, 2011. https://floram.org/article/doi/10.4322/ floram.2011.039

FARIA, R.Q.; TEIXEIRA, I.R.; CUNHA, D.A.D.; HONORATO, J.M.; DEVILLA, I.A. Physiological quality of crambe seeds submitted to drying. Revista Ciência Agronômica, v.45, n.3, p.453-460, 2014. http://www.scielo.br/scielo.php?script=sci_arttext\&pid=S1806$66902014000300004 \& \operatorname{lng}=\mathrm{en} \& \mathrm{nrm}=$ iso

FERREIRA, D. F. Sisvar: a computer statistical analysis system. Ciência e Agrotecnologia, v.35, n.6, p.1039-1042, 2011. https://doi. org/10.1590/S1413-70542011000600001

FLEMING, M.B.; RICHARDS, C.M.; WALTERS, C. Decline in RNA integrity of dry-stored soybean seeds correlates with loss of germination potential. Journal of Experimental Botany, v.68, n.9, p.2219-2230, 2017. https://doi.org/10.1093/jxb/erx100

FREITAS, M.J.L.; SILVA, B.C.; CECHIN, N.F.; JANNER, K.E.; ABIB, E.N. Influência de dois métodos de superação de dormência na germinação de canafístula (Peltophorum dubium Taubert). Anais do Salão Internacional de Ensino, Pesquisa e Extensão, v.7, n.4, 2016. http://200.132.146.161/index.php/siepe/article/view/15387

GARCIA, C.; COELHO, C.M.M.; MARASCHIN, M.; OLIVEIRA, L. M. Conservação da viabilidade e vigor de sementes de Araucaria angustifolia (Bert.) O. Kuntze durante o armazenamento. Ciência Florestal, v.24, n.4, p.857-866, 2014. https://periodicos.ufsm.br/ index.php/cienciaflorestal/article/viewFile/16586/pdf_1

GUEDES, R.S.; ALVES, E.U.; BRUNO, R.L.A.; GONÇALVES, E.P.; COSTA, E.G.; MEDEIROS, M.S. Armazenamento de sementes de Myracrodruon urundeuva Fr. All. em diferentes embalagens e ambientes. Revista Brasileira de Plantas Medicinais, v.14, n.1, p.6875, 2012. http://www.scielo.br/scielo.php?script=sci_arttext\&pid=S1516-05722012000100010\&lng=en\&nrm=iso

GUOLLO, K.; POSSENTI, J.C.; FELIPPI, M.; DEL QUIQUI, E.M.; LOIOLA, T.M. Avaliação da qualidade fisiológica de sementes florestais através do teste de condutividade elétrica. Colloquium Agrariae, v.13, n.1, p.86-92, 2017. http://revistas.unoeste.br/index.php/ ca/article/view/1615

HONG, T.D.; ELLIS, R.H. Storage. In: VOZZO, J.A. (Ed). Tropical Tree Seed Manual. Washington: USDA Forest Service, pp. 125-136. 2002.

ISTA. International Rules for Seed Testing. Zürich. 2004. 174p.

JEROMINI, T.S.; MARTINS, C.C.; PEREIRA, F.E.C.B.; GOMES-JUNIOR, F.G. Raios X na avaliação da qualidade de sementes de Brachiaria brizantha durante o beneficiamento. Revista Ciência Agronômica, v.50, n.3, p.439-446, 2019. http://www.scielo.br/ scielo.php?script=sci_arttext\&pid=S1806-66902019000300439\&Ing=en\&nrm=iso

KAISER, H.F. The application of electronic computers to factor analysis. Educational and Psychological Measurement, v. 20, p. 141-151, 1960. https://doi.org/10.1177/001316446002000116 
KOTTEK, M.; GRIESER, J.; BECK, C.; RUDOLF, B.; RUBEL, F. World map of the Köppen-Geiger climate classification updated. Meteorologische Zeitschrift, v.15, n.3, p.259-263, 2006. https://doi.org/10.1127/0941-2948/2006/0130

KRANNER, I.; CHEN, H.; PRITCHARD, H.W.; PEARCE, S.R.; BIRTIC, S. Inter- nucleosomal DNA fragmentation and loss of RNA integrity during seed aging. Plant Growth Regulation, v.63, n.1, p.63-72, 2011. https://link.springer.com/article/10.1007/s10725-010-9512-7

LABOURIAU, L.G. The Germination of Seeds. OEA, Washington, 1983, 174p.

LINGINGTON, S.; MANGER, K. Seed bank design: seed drying rooms. Technical Information Sheet_11, Royal Botanic Gardens Kew, UK, p. 1-4, 2014.

MAGUIRE, J.D. Speed of germination-aid in selection and evaluation for seedling emergence and vigor. Crop Science, v.2, p.176-177, 1962. https://acsess.onlinelibrary.wiley.com/doi/abs/10.2135/cropsci1962.0011183X000200020033x

MANNING, K. Isolation of nucleic acids from plants by differential solvent precipitation. Analytical Biochemistry, v. 195, n. 1, p. 4550, 1991. https://www.sciencedirect.com/science/article/abs/pii/0003269791902922

NOGUEIRA-FILHO, F.P.; OLIVEIRA, A. B.; PEREIRA, M.S; LOPES, M. D. F.Q.; SILVA, R. T. Efetividade do teste de raios x para avaliação da qualidadefisiológica desementes degergelimemfunçãodaposiçãodosfrutosna planta.RevistaBrasileirade CiênciasAgrárias, v.12,n.4, p. 435-440, 2017. http://www.agraria.pro.br/ojs-2.4.6/index.php?journal=agraria\&page=article\&op=view\&path\%5B\%5D=agraria_ v12i4a5474

OLIVEIRA-BENTO, S.D.E.; TORRES, S.B.; BENTO, D.A.V.; SILVA, B.K.D.A.; DANTAS, F.J.C.; MELO, V.D.C. Armazenamento de sementes de flor-de-seda [Calotropis procera (AITON) W.T. aiton]. Revista Caatinga, v.28, n.1, p.49-47, 2015. https://www.redalyc.org/ pdf/2371/237138297005.pdf

OLIVEIRA-FILHO, A.T.; VILELA, E.D.A.; CARVALHO, D.D.; GAVILANES, M.L. Estudos Florísticos e Fitossociológicos em Remanescentes de Matas Ciliares do Alto e Médio Rio Grande. Belo Horizonte: Boletim técnico, v. 11, 1995.

OLIVA, M.L.V; NAKAHATA, A.M.; SAMPAIO, M.U.; JASIULIONIS, M.G. Use of protease inhibitors from Bauhinia bauhinioides and/or Enterolobium contortisiliquum. Depositantes: Maria Luiza Vilela Oliva, Adriana Miti Nakahata, Misako Uemura Sampaio e Miriam Galvonas Jasiulionis. WO2007112531A1. Depositado: 06 de abr. 2006. Concessão: 11 de Nov. 2007.

PESKE, S.T.; VILLELA, F. A.; MENEGHELLO, G. E. Sementes: fundamentos científicos e tecnológicos. Pelotas: UFPel, 2012, 573p.

RESENDE, O.; ULLMANN, R.; SIQUEIRA, V.C.; CHAVES, T.H.; FERREIRA, L.U. Modelagem matemática e difusividade efetiva das sementes de pinhão-manso (Jatropha curcas L.) durante a secagem. Engenharia Agrícola, v.31, n.6, p.1123-1135, 2011. http:// www.scielo.br/scielo.php?script=sci_arttext\&pid=S0100-69162011000600010\&lng=en\&nrm=iso

RIBEIRO, D.M.; BRAGANÇA, S.M.; GONELI, A.L.D.; DIAS, D.C.F.S.; ALVARENGA, E.M. Teste de condutividade elétrica para avaliar o vigor de sementes em milho-pipoca (Zea mays L.). Revista Ceres, v.56, n.6, p.772-776. 2009. http://www.ceres.ufv.br/ojs/index. php/ceres/article/view/3503/1393

ROCHA, G.C.; NETO, A.R.; CRUZ, S.J.S.; CAMPOS, G.W.B.; OLIVEIRA CASTRO, A.C.; SIMON, G.A. Qualidade fisiológica de sementes de soja tratadas e armazenadas. Científic@-Multidisciplinary Journal, v.4, n.1, p.50-65, 2017. https://doi.org/10.29247/2358260X.2017v4i1.p50-65

SANTOS, S.R.G.; PAULA, R.C. Teste de condutividade elétrica para avaliação da qualidade fisiológica de sementes de Sebastiania commersoniana (Bail.) Smith \& Downs (branquilho) - Euphorbiaceae. Revista Brasileira de Sementes, v.27, n.2, p.136-145, 2005. http://www.scielo.br/scielo.php?script=sci_arttext\&pid=S0101-31222005000200020\&lng=en\&nrm=iso

SILVA, K.R.G.; VILLELA, F.A. Pré-hidratação e avaliação do potencial fisiológico de sementes de soja. Revista Brasileira de Sementes, v.33, n.2, p.331-345, 2011. http://www.scielo.br/scielo.php?script=sci_arttext\&pid=S0101-31222011000200016\&lng=en\&nrm=iso

SILVA, J.R.O.; ALBUQUERQUE, M.C.F.; SILVA, I.C.O. Armazenamento de sementes de Parkia pendula (Willd.) Benth. ex Walp. (FABACEAE) em diferentes embalagens e ambientes. Floresta e Ambiente, v.21, n.4, p.457-467, 2014. http://www.scielo.br/scielo. php?script=sci_arttext\&pid=S2179-80872014000400005\&lng=en\&nrm=iso

VERGARA, R.O.; MONTEIRO, R.D.C.M.; GADOTTI, G.I.; MOREIRA, I.B. Temperatura de secagem e qualidade de sementes de arroz/drying temperature and rice seed quality. Brazilian Journal of Development, v.6, n.4, p. 22524-22530, 2020. https://www. brazilianjournals.com/index.php/BRJD/article/view/9405/7935 
WIELEWICKI, A.P.; LEONHARDT, C.; SCHLINDWEIN, G.; MEDEIROS, A.C.D.S. Proposta de padrões de germinação e teor de água para sementes de algumas espécies florestais presentes na região sul do Brasil. Revista Brasileira de Sementes, v.28, n.3, p.191-197, 2006. http://www.scielo.br/scielo.php?script=sci_arttext\&pid=S0101-31222006000300027\&lng=en\&nrm=iso use, distribution, and reproduction in any medium, provided the original work is properly cited. 